\title{
The comparison of creatinine and cystatin $C$ value in preeclampsia severity and neonatal outcome
}

\author{
John Wantania, Abraham Winarto \\ Department of Obstetrics and Gynecology \\ Faculty of Medicine, Sam Ratulangi University, Prof dr. RD Kandou Hospital, Manado
}

\begin{abstract}
ABSTRAK
Tujuan: membandingkan kadar kreatinin dan cystatin $\mathrm{C}$ dengan keparahan preeklampsia, serta menilai luaran neonatalnya.

Bahan dan Metode: Dilakukan pemeriksaan kreatinin dan cystatin C, dan luaran neonatal pada 17 sampel kelompok normotensi, 17 sampel preeklampsia ringan (PER) dan 17 sampel preeklampsia berat (PEB). Analisa data dengan uji statistik anova dan dengan uji t perbedaan antar 2 proporsi.

Hasil: Kadar rerata kreatinin pada kelompok Normotensi, PER, PEB yaitu $0,56 \mathrm{mg} / \mathrm{dL}, 0,67 \mathrm{mg} / \mathrm{dL}$, dan $0,75 \mathrm{mg} / \mathrm{dL}, \mathrm{p}=0,138$; Sedangkan pada cystatin C yaitu $0,82 \mathrm{mg} / \mathrm{L}, 1,03 \mathrm{mg} / \mathrm{L}$, dan 1,32 $\mathrm{mg} / \mathrm{L}, \mathrm{p}=0,000$. Tidak ditemukan luaran neonatal yang buruk pada kelompok normotensi. Pada kelompok PER didapatkan 1 bayi lahir preterm dan 1 bayi IUFD, sedangkan pada kelompok PEB didapatkan 3 bayi lahir preterm, 1 bayi IUFD, dan 1 bayi IUGR.

Simpulan: kadar cystatin $\mathrm{C}$ meningkat secara bermakna seiring dengan peningkatan keparahan preeklampsia, sedangkan kreatinin tidak meningkat secara bermakna. Cystatin $\mathrm{C}$ merupakan penanda gangguan fungsi ginjal pada pasien preeklampsia yang lebih baik dibandingkan kreatinin. Terdapat peningkatan luaran neonatus yang buruk pada kelompok preeklampsia.
\end{abstract}

Kata Kunci: kreatinin, cystatin C, preeklampsia, luaran neonatal

\section{INTRODUCTION}

Preeclampsia is a pregnancy pathology which causes health problems to mothers and their unborn babies because of its incidence and mortality both in the world and in Indonesia. In the whole world, pre-eclampsia has caused 50,000 maternal deaths and 900,000 perinatal deaths annually. The incidence of preeclampsia in pregnancy is $5-10 \%$ and becomes one of the three main causes of maternal mortality after bleeding and infection. Indonesia's maternal mortality remains dominated by three major causes of death which are hemorrhage, hypertension in pregnancy, and infection. The proportion among those three causes of maternal death has changed, as bleeding and infection tend to decrease while hypertension in pregnancy proportion is increasing. ${ }^{1-3}$ Preeclampsia is a disorder of various organ systems which is characterized by hypertension and proteinuria after 20 weeks of pregnancy. Preeclampsia is originated from defects of trophoblast invasion and

\begin{abstract}
Objectives: to compare the levels of creatinine and cystatin $\mathrm{C}$ with the severity of preeclampsia, and assess neonatal outcomes. Materials and Methods: Creatinine, cystatin C, and neonatal outcomes were assesed in 17 normotensive samples, 17 samples of mild preeclampsia and 17 samples of severe preeclampsia. Analysis of data with statistical tests of ANOVA and test differences between 2 proportions.

Results: The mean levels of creatinine in the normotensive group, mild preeclampsia, severe preeclampsia are $0.56 \mathrm{mg} / \mathrm{dL}, 0.67 \mathrm{mg} /$ $\mathrm{dL}$, and $0.75 \mathrm{mg} / \mathrm{dL}, \mathrm{p}=0.138$; While on cystatin $\mathrm{C}$ are $0.82 \mathrm{mg} / \mathrm{L}$, $1.03 \mathrm{mg} / \mathrm{L}$ and $1.32 \mathrm{mg} / \mathrm{L}, \mathrm{p}=0.000$. The adverse neonatal outcome wasn't found in the normotensive group. In mild preeclampsia obtained 1 preterm birth and 1 intrauterine fetal death (IUFD), whereas in severe preeclampsia obtained 3 babies born preterm, 1 IUFD, and 1 intrauterine growth restriction (IUGR). Conclusion: levels of cystatin $\mathrm{C}$ was increased significantly in line with increased severity of preeclampsia, whereas creatinine was not increased significantly. Cystatin $\mathrm{C}$ is better than creatinine as a marker of renal dysfunction in preeclampsia patients. There was an increase in adverse neonatal outcomes in the group of preeclampsia.
\end{abstract}

Keywords: creatinine, cystatin C, preeclampsia, neonatal outcomes

Correspondence: John Wantania, Department of Obstetrics and Gynecology, Prof Dr RD Kandou Hospital, Jalan Raya

Tanawangko, Manado, North Sulawesi, 95115. Phone: 0431-959178, 859177. E-mail : john_w_md@yahoo.com

the spiral arteries remodeling that then lead to placental ischemia. These placental ischemia causes the placenta to produce soluble factors that cause endothelial dysfunction. The clinical features of preeclampsia causes kidney, as the main target organ, to experience glomerular endotheliosis that causes a decrease in glomerular filtration rate. ${ }^{4,5}$

Preeclampsia and eclampsia are $75 \%$ of the causes of acute renal failure in pregnancy. Thus, impaired kidney function is a component that should be a major concern in preeclampsia. Renal function monitoring is necessary so that earlier treatment can be implemented to prevent further kidney damage. Creatinine and cystatin $\mathrm{C}$ is a marker of kidney function that can be used in preeclampsia. Exchange of low molecular weight substances such as creatinine and cystatin $\mathrm{C}$ occurred in the kidney. Creatinine is a biomarker of kidney function that is most widely used. 6-8 $^{-8}$ 
Creatinine is the anhydride form of creatine anhydride produced as the end product of phospho-creatine decomposition. Creatinine is eliminated by renal glomerular filtration and a little amount of it sis secreted by renal tubular. Creatinine excretion depends on skeletal muscle mass, age, gender and diet. Serum creatinine level increases in patients with renal impairment, especially with a significant reduction in glomerular filtration. ${ }^{4,9,10}$

Serum creatinine is limited in assessing the glomerular filtration rate, because a decrease in glomerular filtration rate of up to $50 \%$ can be without an increased serum creatinine concentration. The average level of creatinine in preeclampsia does not always rise above the reference limit which is appropriate for normal pregnancy, and this reduces the usefulness of these parameters to monitor the occurrence of renal dysfunc-tion in patients with preeclampsia. Creatinine is unable to detect a decrease in glomerular filtration rate in the early stages of kidney dysfunction, therefore it is important to use new biomarkers such as cystatin C. Serum cystatin $\mathrm{C}$ is an endogenous marker of renal function. Cystatin $\mathrm{C}$ is synthesized by all nucleated cells and excreted from the body's circulation exclusively through glomerular filtration. From the above explan-ation, the serum cystatin $\mathrm{C}$ has superior diagnostic accuracy as a marker of glomerular endoteliosis or renal involvement in preeclampsia compared to creatin-ine. ${ }^{4,11,12}$

Studies conducted Franceschini et al (2008) and Mona Faraq et al (2011) found that cystatin C levels rise higher in patients with preeclampsia compared than in normotensive pregnancy.Helena Strevens et al (2002) compared the levels of cystatin $\mathrm{C}$, creatinine and uric acid. Cystatin $\mathrm{C}$ has superior diagnostic accuracy for preeclampsia compared with serum uric acid or creatinine. ${ }^{11-13}$

Incidence of perinatal morbidity and mortality is rising in pregnancy with preeclampsia, and this is mainly due to preterm labor and uteroplacental insufficiency, which results in decreased blood flow to the fetus. Prematurity, fetal growth retardation (IUGR), and fetal death (IUFD) are neonatal complications that should be well-anticipated in patients with preeclampsia. ${ }^{14,15}$

Currently there are still few studies of comparative levels of creatinine and cystatin $\mathrm{C}$ in patients with preeclampsia and how the neonatal outcomes are, whereas impaired renal function is an important compo-nent in the pathophysiology of preeclampsia. Close monitoring of renal function is essential to ensure on time delivery before the onset of severe kidney damage that increases neonatal morbidity and maternal mortal-ity. ${ }^{7,16}$

\section{MATERIALS AND METHODS}

This research was a cross sectional analytic approach to assess the comparative levels of creatinine and cystatin $\mathrm{C}$ with the severity of preeclampsia and neonatal outcomes in patients with preeclampsia. The population of this study was the third trimester pregnant women in maternity wards Prof Dr RD Kandou Hospital, Manado and its networking hospitals. Sample collection was done by consecutive sampling. The samples consisted of three groups, as follows: 17 normotensive women, 17 women with mild preeclampsia, and 17 women with severe preeclampsia who meet the inclusion and exclusion criteria.

The inclusion criterias were the third trimester pregnant women with single fetus and willing to participate in the study. While the exclusion criterias were: pregnant women with diabetes mellitus, chronic hypertension, kidney disease, infections, and twin fetus. The research used subjest's blood samples, then examines the levels of creatinine and cystatin $\mathrm{C}$ of those samples in the Prodia laboratory Manado.

Data analysis was done using ANOVA statistical test to compare the levels of creatinine and cystatin $\mathrm{C}$ with the severity of preeclampsia. The data obtained were processed using the software program Statistical Product and Service Solution (SPSS) for Windows version 22. The t-test difference between 2 proportions is used to look for fetal outcomes in patients with preeclampsia. The data obtained are then processed with Stata 10 statistical program.

\section{RESULTS AND DISCUSSION}

A research on the population of aterm pregnant women in Prof. Kandou Hospital and the networking hospitals from August to November 2015 has been done with a total sample of 51 samples consisting of 17 normotensive samples, 17 mild preeclampsia samples, and 17 severe preeclampsia samples. Characteristics of the sample in this study can be seen in Table 1.

This research obtained $0.8 \mathrm{mg} / \mathrm{dL}$ as the highest levels of creatinine for normotensive pregnant woman and 0.4 $\mathrm{mg} / \mathrm{dL}$ as the lowest. In the group of mild preeclampsia, the highest level of creatinine was $1.1 \mathrm{mg} / \mathrm{dL}$ and the lowest level was $0.4 \mathrm{mg} / \mathrm{dL}$. In severe preeclampsia group, the highest level of creatinine was $1.1 \mathrm{mg} / \mathrm{dL}$ and the lowest level was $0.5 \mathrm{mg} / \mathrm{dL}$ (Figure 1). ANOVA statistical test showed that there was no significant difference in creatinine levels among those three groups 
(normotensive, mild preeclampsia and severe preeclampsia), with a value of $p=0.138$ (Table 2).

This research obtained $1.11 \mathrm{mg} / \mathrm{L}$ as the highest levels of cystatin $\mathrm{C}$ for normotensive pregnant women and the $0.66 \mathrm{mg} / \mathrm{L}$ as the lowest level. In the group of mild preeclampsia, the highest levels of cystatin $\mathrm{C}$ was 1.25 $\mathrm{mg} / \mathrm{L}$ and the lowest level was $0.83 \mathrm{mg} / \mathrm{L}$. At the severe preeclampsia group, the highest levels of cystatin $\mathrm{C}$ concentration was $1.58 \mathrm{mg} / \mathrm{L}$ and the lowest level was $0.98 \mathrm{mg} / \mathrm{L}$. ANOVA statistical test showed that $p=0.000$ which shows that the level of cystatin $\mathrm{C}$ in normotensive is different with in the mild preeclampsia and the severe preeclampsia groups.

In this study, ANOVA test on creatinine and cystatin C showed that cystatin $\mathrm{C}$ increased significantly along with an increase in the severity of preeclampsia, while creatinine did not increase significantly.

Table 1. Characteristics of research subjects

\begin{tabular}{|c|c|c|c|c|c|c|}
\hline \multirow[b]{2}{*}{ Characteristics } & \multicolumn{2}{|c|}{ Normotensive } & \multicolumn{2}{|c|}{ MPE } & \multicolumn{2}{|c|}{ SPE } \\
\hline & $\mathrm{N}$ & $\%$ & $\mathrm{~N}$ & $\%$ & $\mathrm{~N}$ & $\%$ \\
\hline \multicolumn{7}{|l|}{ Maternal age } \\
\hline$\leq 20$ years & 4 & 23.5 & - & - & 2 & 11.8 \\
\hline 21-35 years & 10 & 58.8 & 12 & 70.6 & 9 & 52.9 \\
\hline$\geq 35$ years & 3 & 17.6 & 5 & 29.4 & 6 & 35.3 \\
\hline \multicolumn{7}{|l|}{ Parity } \\
\hline primigravida & 7 & 41.2 & 4 & 23.5 & 6 & 35.3 \\
\hline multigravida & 10 & 58.8 & 13 & 76.5 & 11 & 64.7 \\
\hline \multicolumn{7}{|l|}{ Work } \\
\hline Housewives & 13 & 76.5 & 14 & 82.4 & 15 & 88.2 \\
\hline $\begin{array}{l}\text { Private } \\
\text { section }\end{array}$ & 3 & 17.6 & 2 & 11.8 & - & - \\
\hline Students & - & - & - & - & 1 & 5.9 \\
\hline $\begin{array}{l}\text { Government } \\
\text { employees }\end{array}$ & - & - & 1 & 5.9 & 1 & 5.9 \\
\hline Farmer & 1 & 5.9 & - & - & - & - \\
\hline \multicolumn{7}{|l|}{ Tribe } \\
\hline Minahasa & 15 & 88.2 & 15 & 88.2 & 16 & 94.1 \\
\hline Java & 2 & 11.8 & 2 & 11.8 & 0 & - \\
\hline Gorontalo & - & - & - & - & 1 & 5.9 \\
\hline \multicolumn{7}{|l|}{$\begin{array}{l}\text { Number } \\
\text { Marriages }\end{array}$} \\
\hline 1 & 17 & 100 & 17 & 100 & 15 & 88.2 \\
\hline 1 & - & - & - & - & 2 & 11.8 \\
\hline
\end{tabular}

Table 2. Statistical analysis of creatinine levels

\begin{tabular}{lrlll}
\hline & \multicolumn{4}{c}{ Serum creatinine } \\
\cline { 2 - 5 } & $\begin{array}{c}\text { Levels } \\
(\mathrm{mg} / \mathrm{dL})\end{array}$ & $\begin{array}{c}\text { Mean } \\
(\mathrm{mg} / \mathrm{dL})\end{array}$ & $\mathrm{SD}$ & P value \\
\hline $\begin{array}{l}\text { Normotensive } \\
\begin{array}{l}\text { Mild } \\
\text { preeclampsia }\end{array}\end{array}$ & $0.40-0.80$ & 0.56 & 0152 & 0.138 \\
$\begin{array}{l}\text { Severe } \\
\text { preeclampsia }\end{array}$ & $0.40-1.10$ & 0.67 & 0180 & \\
\hline
\end{tabular}

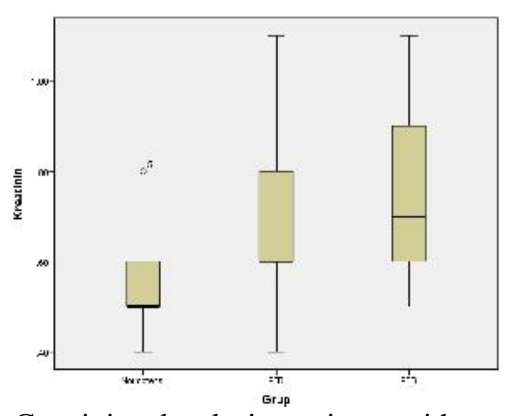

Figure 1. Creatinine levels in patients with normotensive, mild preeclampsia, severe preeclampsia

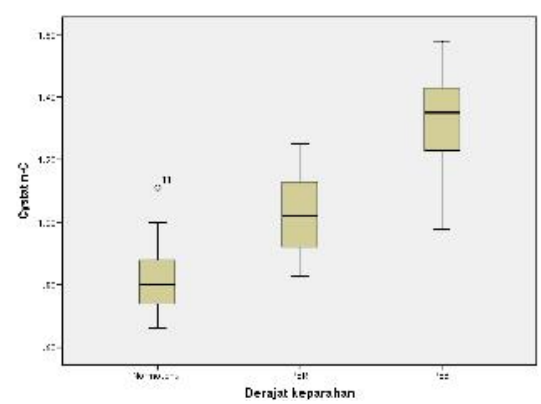

Figure 2. Cystatin C levels in patients with normotensive, mild preeclampsia, and severe preeclampsia

Table 3. Statistical analysis of cystatin c levels

\begin{tabular}{lcccc}
\hline & \multicolumn{4}{c}{ Cystatin C } \\
\cline { 2 - 5 } & $\begin{array}{c}\text { Levels } \\
(\mathrm{mg} / \mathrm{dL})\end{array}$ & $\begin{array}{c}\text { Mean } \\
(\mathrm{mg} / \mathrm{dL})\end{array}$ & $\mathrm{SD}$ & $\begin{array}{c}\mathrm{P} \\
\text { value }\end{array}$ \\
\hline $\begin{array}{l}\text { Normotensive } \\
\begin{array}{l}\text { Mild } \\
\text { preeclampsia }\end{array}\end{array}$ & $0.66-1.11$ & 0.82 & 0124 & 0000 \\
$\begin{array}{l}\text { Severe } \\
\text { preeclampsia }\end{array}$ & $0.83-1.25$ & 1.03 & 0121 & \\
\hline
\end{tabular}

Fetal outcomes in this study showed that there was no bad fetal outcome in the normotensive group. In mild preeclampsia group, the result showed one baby was born preterm and 1 IUFD. In severe preeclampsia group, the result showed three babies born preterm, 1 IUGR, and 1 IUFD. The results of T test differences between 2 proportions by using a statistical program Stata 10 were (Table 4): There were no significant differences in the proportion of preterm infants between the MPE and SPE group $\rightarrow \mathrm{p}=0.287$ (the proportions are $1 / 17$ and 3/17). There were no significant differences in the proportion of IUFD between the MPE and SPE group $\rightarrow p=1.000$ (the proportions are $1 / 17$ and 1/17).

In this study the characteristics of the samples assessed were maternal age, parity, employment, marriage, and 
the tribe. In Table 1 we can see the comparison of sample characteristics in each blood pressure category, such as normotensive, mild preeclampsia and severe preeclampsia. The distribution of study subjects according to age group was 15 to 42 years. The highest percentage of the age group was at 21-34 years old, of the parity was the multiparous pregnant women, of the tribe was the Minahasa tribe.

Table 4. Relationship between neonatal outcomes with preeclampsia

\begin{tabular}{lllllll}
\hline \multirow{2}{*}{$\begin{array}{l}\text { Neonatal } \\
\text { outcomes }\end{array}$} & \multicolumn{2}{c}{ Normotensive } & & \multicolumn{2}{c}{ MPE } & \multicolumn{2}{c}{ SPE } \\
\cline { 2 - 7 } \cline { 5 - 7 } Preterm & - & $\%$ & $\mathrm{~N}$ & $\%$ & $\mathrm{~N}$ & $\%$ \\
IUGR & - & - & 1 & $1 / 17$ & 3 & $3 / 17$ \\
IUFD & - & - & - & - & 1 & $1 / 17$ \\
\hline
\end{tabular}

The creatinine's average levels in this study were not significantly different between normotensive pregnancy group, mild preeclampsia and severe preeclampsia, which were $0.56 \mathrm{mg} / \mathrm{dL}, 0.67 \mathrm{mg} / \mathrm{dL}$, and $0.75 \mathrm{mg} / \mathrm{dL}$, with a value of $p=0.138$. Therefore, it can be concluded that the creatinine levels did not increase significantly along with the severity of preeclampsia. These creatinine results were different compared to the cystatin $\mathrm{C}$ results. Serum cystatin $\mathrm{C}$ level between normotensive pregnancy group with mild preeclampsia and with severe preeclampsia, were not significantly different. The results were $0.82 \mathrm{mg} / \mathrm{l}, 1.03 \mathrm{mg} / \mathrm{L}$ and $1.32 \mathrm{mg} / \mathrm{L}$, with $\mathrm{p}=0,000$. Therefore, with ANOVA test towards creatinine and cystatin $\mathrm{C}$, it can be concluded cystatin $\mathrm{C}$ level will increase significantly along with an increase in the severity of preeclampsia, whereas creatinine will not increase significantly.

This research supports the research conducted by Shalvi Sharma et al (2014) who obtained serum cystatin $C$ is more superior as a marker of renal dysfunction compared to creatinine in patients with preeclampsia. Cystatin $\mathrm{C}$ concentration was significantly higher in patients with preeclampsia $(1.31 \pm 0.4 \mathrm{mg} / \mathrm{L})$ compared to normotensive pregnant women $(0.96 \pm 0.2 \mathrm{mg} / \mathrm{L})$, with $\mathrm{p}<0.001$. On the contrary, creatinine concentration was not significantly increased in patients with preeclampsia $(0.71 \pm 0.09 \mathrm{mg} / \mathrm{dL})$ compared to normotensive pregnant women $(0.7 \pm 0.08 \mathrm{mg} / \mathrm{dL})$, with $\mathrm{p}=0.907$. Another research conducted by Kurnia et al (2014), compared 19 cases of severe preeclampsia and 25 cases of normal pregnancy, found a significantly different cystatin $\mathrm{C}$ levels in severe preeclampsia compared with normal pregnancy. The mean levels of serum cystatin $\mathrm{C}$ in severe preeclampsia was $1.16 \pm 0.31 \mathrm{mg} / \mathrm{L}$ and in the normotensive woman was $0.92 \pm 0.16 \mathrm{mg} / \mathrm{L}$. $(17,18)$
A study conducted by Sumithra et al (2013) also obtained similar results with our study, in which the cystatin C increased significantly in preeclampsia patients, while creatinine remained within normal limits. The average level of creatinine in the preeclamptic group was $0.61 \pm 0.17 \mathrm{mg} / \mathrm{dL}$ and in the control group was $0.47 \pm 0.08 \mathrm{mg} / \mathrm{dL}$. The average levels of cystatin $\mathrm{C}$ in preeclampsia group was $1.29 \pm 0.4 \mathrm{mg} / \mathrm{L}$ and in the control group was $0.13 \pm 0.77 \mathrm{mg} / \mathrm{L}$. There was no signifi-cant increase of creatinine in the preeclampsia group. ${ }^{4}$

Creatinine is a biomarker that has been used extensively as a marker of kidney function but is less sensitive in the early stages of kidney dysfunction. In the oher hand, Cystatin $\mathrm{C}$ is very sensitive in assessing changes in glomerular filtration rate on the early stages of renal impairment. Furthermore, unlike creatinine, cystatin C was not significantly affected by diet, infections, liver function, malignancy, muscle mass and fat in evaluating glomerular filtration rate, so that cystatin $\mathrm{C}$ can be a better screening test for early detection of renal dysfunction in patients with preeclampsia, compared to creatinine. ${ }^{4,6,12}$

The increased mean of cystatin $\mathrm{C}$ levels in patients with preeclampsia, which was due to renal morphological changes characterized by endotheliosis, will inhibit glomerular filtration, resulting in decreased rate of glomerular fitration. Cystatin $\mathrm{C}$ which has a small molecular weight, freely goes through the glomerular membrane. Unlike creatinine, cystatin $\mathrm{C}$ is not secreted by the tubules but fully filtered by the glomerulus then resorbed and catabolized by the kidney tubules. Thus, cystatin $\mathrm{C}$ levels can be highly sensitive in depicting a decrease in glomerular filtration rate. ${ }^{17,18}$ Creatinine levels increased in patients with impaired renal function with severely decreased glomerular filtration rate, so normal serum creatinine cannot exclude an impaired renal function condition. Creatinine is unable to detect a decrease in glomerular filtration rate in the early stages of kidney dysfunction, therefore it is important to use new biomarkers such as Cystatin $\mathrm{C}$ since it has a superior diagnostic accuracy in preeclamp-sia compared to creatinine. ${ }^{4,13,18}$

A study of renal biopsy performed by Strevens et al (2003), found that cystatin C levels were correlated with the severity of renal structural changes (glomerular endoteliosis) that are typical in patients with preeclampsia. Research by Roberto Costa et al (2015), stated that there was a link between serum cystatin $\mathrm{C}$ levels with proteinuria levels. Patients with severe proteinuria have higher cystatin $\mathrm{C}$ levels compared to 
patients with mild proteinuria. Glomerular cell damage results in increased permeability of the basement membrane, causing leaks that leads to proteinuria. Cystatin $\mathrm{C}$ is a marker of kidney function that can be relied upon in assessing the severity of glomerular cell damage. The declining of kidney function in preeclampsia needs to be assessed so that the delivery will be arranged in the right time before the onset of severe renal impairment. ${ }^{4,10,17,19}$

In this study, there was an increase in bad neonatal outcomes in preeclampsia group which was not found in the normotensive group. The mild preeclampsia group got one baby born preterm and 1 IUFD. In severe preeclampsia group, there were three babies born preterm, 1 IUFD, and 1 IUGR. The $\mathrm{T}$ test differences between 2 proportions using Stata 10 statistical program showed that there are no significant differences of preterm infants and IUFD proportion between mild preeclampsia and severe preeclampsia groups, with $p=0.287$ and $p=1.000$.

The increasing incidence of perinatal morbidity and mortality in pregnancy with preeclampsia, is mainly due to preterm labor and uteroplacental insufficiency which result in decreased blood flow (oxygen supply and nutrients) to the fetus. Prematurity, growth retardation and fetal mortality are neonatal complications that should be well anticipated and dealt in patients with preeclampsia. $^{14,15}$

A cohort study done by Young et al, found that the relative risk of neonatal death rate was at 34-42 weeks gestational age group, using 40 weeks as the reference. Researchers showed the relative risk of neonatal mortality decreased with the increasing gestational age. In particular, the infant mortality rate of babies bein born in gestational ages of 34,35 , and 36 weeks were respectively $12.5 ; 8.7$; and 6.3 times higher, compared to aterm pregnancy (40 weeks) as a control. ${ }^{20}$

In the past, epidemiological research and patient care guidelines, suggested 34 weeks of pregnancy as fetal maturity age. Babies born between 34 and 36 weeks of pregnancy were termed as "near term" baby and believed to be at low risk for significant morbidity. This causes relatively lack of concern about the consequences of neonatal birth above 34 weeks gestation. However, later on, literatures indicated that extendedd premature babies ( $\geq 34$ weeks) have a greater risk for a number of complications, especially respiratory problems. Several studies have shown that premature babies have an increased risk of further occurrence of respiratory distress syndrome (RDS), transient tachypnea of the newborn (TTN), persistent pulmonary hypertension $(\mathrm{PPH})$ and respiratory failure compared with term infants. ${ }^{14}$

Preeclampsia is a significant risk factor for the occurrence of intrauterine fetal death, with an estimated fetal mortality rate of 21 per 1000 . In severe preeclampsia the risk of fetal death should be considered beyond the benefits of continuing pregnancy. However, in mild preeclampsia cases, the risk of fetal death is less than $50 \%$ of severe preeclampsia. Considering fewer risks of intrauterine fetal death occurence in mild preeclampsia, the childbirth could be delayed until 37 weeks for intrauterine fetal maturation purposes. ${ }^{14}$

Growth is a marker of fetal well-being. Pregnancies with intrauterine growth restrict-ion (IUGR) were associated with increased perinatal mortality. In preeclampsia, decreased uteroplacental blood flow and ischemia are significant risk factors for IUGR and the most common cause of IUGR in non-anomaly infants. Body weight below the 10th percentile significantly increase the risk of neonatal mortality.

Therefore, infants weighing 1,250 grams at 38-40 weeks gesta-tional age had significantly greater risk of death compared with 32 weeks gestational age infants with the same body weight. Babies born from pregnancy with severe preeclampsia have $12 \%$ lower birth weight than expected, while the pregnancy with mild preeclampsia showed no difference in the birth weight compared to a normal pregnancy. This is consistent with the results of our study which did not obtain IUGR in mild preeclampsia group. ${ }^{14}$

\section{CONCLUSION}

From this study we found that cystatin $\mathrm{C}$ level will increase significantly along with an increase in the severity of preeclampsia, while creatinine will not increase significantly. Cystatin $\mathrm{C}$ is a better marker of renal dysfunction in patients with preeclampsia compared to creatinine. Preeclampsia group of mothers will have worse neonatal outcomes compared to the normotensive group. The bad outcomes were: prematurity, IUGR, and IUFD.

\section{REFERENCES}

1. Chappell S, Morgan L. Searching for genetic clues to the causes of pre-eclampsia. Clin Sci (Lond). 2006;110(4):443-58. 
2. Kementrian Kesehatan. Profil Kesehatan Indonesia Tahun 2013. Jakarta: Kementerian Kesehatan RI; 2014. hal. 507.

3. Takahashi WH, Silvio M, Khoury MY, Lopes RGC, Garcia SAL, Lippi UG. Assessment of serum lipids in pregnant women aged over 35 years and their relation with pre-eclampsia. 2008.

4. Sumithra K, Vibha C, Vishwanath HL. Studyof Serum Cystatin C in Pre-Eclampsia.

5. Kristensen K, Wide-Swensson D, Schmidt C, Blirup-Jensen S, Lindström V, Strevens H, et al. Cystatin C, beta-2-microglobulin and beta-trace protein in pre-eclampsia. Acta Obstet Gynecol Scand. 2007;86(8):921-6.

6. Mares J, Stejskal D, Vavrousková J, Urbánek K, Herzig R, Hlustík P. Use of cystatin C determination in clinical diagnostics. Biomed Pap Med Fac Univ Palacky Olomouc Czech Repub. 2003;147(2):177-80.

7. Padma Y, Aparna VB, Kalpana B, Ritika V, Sudhakar PR. Renal markers in normal and hypertensive disorders of pregnancy in Indian women: a pilot study. Int J Reprod Contraception. Obstet Gynecol. 2013;2(4):514-20.

8. Filler G, Bökenkamp A, Hofmann W, Le Bricon T, Martínez-Brú C, Grubb A. Cystatin C as a marker of GFR-history, indications, and future research. Clin Biochem. 2005;38(1):1-8.

9. Garovic VD, Wagner SJ, Turner ST, Rosenthal DW, Watson WJ, Brost BC, et al. Urinary podocyte excretion as a marker for preeclampsia. Am J Obstet Gynecol. 2007;196(4):1-7.

10. Strevens H, Wide-Swensson D, Grubb A, Hansen A, Horn T, Ingemarsson I, et al. Serum cystatin C reflects glomerular endotheliosis in normal, hypertensive and pre-eclamptic pregnancies. BJOG An Int J Obstet Gynaecol. Blackwell Science Ltd. 2003;110(9):825-30.
11. Farag MK, Maksoud NA El, Ragab HM, Gaber KR. Predictive value of cystatin $\mathrm{C}$ and beta-2 microglobulin in preeclampsia. J Genet Eng Biotechnol. 2011;9(2):133-6.

12. Strevens H, Justnu. Blood pressure, renal functional and structural changes, in normal and preeclamptic pregnancy. Helena Strevens, Department of Obstetrics and Gynecology, University Hospital Sweden. 2002;221(85).

13. Franceschini N, Qiu C, Barrow DA, Williams MA. Cystatin C and preeclampsia: a case control study. Ren Fail. 2008;30(1):89-95.

14. Backes $\mathrm{CH}$, Markham K, Moorehead P, Cordero L, Nankervis CA, Giannone PJ, et al. Maternal Preeclampsia and Neonatal Outcomes. J Pregnancy. Hindawi Publishing Corporation. 2011:1-7.

15. Aabidha PM, Cherian AG, Paul E, Helan J. Maternal and fetal outcome in pre-eclampsia in a secondary care hospital in South India. J Fam Med Prim care. 2015;4(2):257-60.

16. Roberts JM, Gammill HS. Preeclampsia: recent insights. Hypertension. 2005;46(6):1243-9.

17. Sharma S, Ranjan RK, Gupta M, Singh A, Gupta R, Pant L. Original Article Serum Cystatin C compared with conventional renal function tests: A study in patients with pre-eclampsia. 2014;1(2):6-9.

18. Isasari, et al. Maternal Cystatin C Serum is Higher in Women with Severe Preeclampsia. Indones J Obs Gynecol. 2014;2(1):22-7.

19. Costa RA, Peracoli MT, Romão M, Weel IC, Abbade JF, Peracoli JC. Pregnancy Hypertens An Int J Women's Cardiovasc Heal. Elsevier; 2015;5(1):64.

20. Young PC, Glasgow TS, Li X, Guest-Warnick G, Stoddard G. Mortality of late-preterm (near-term) newborns in Utah. Pediatrics. 2007;119(3):659-65. 